Article

\title{
Lamòling Bèaka: Immanence, Rituals, and Sacred Objects in an Unwritten Legend in Alor
}

\author{
Francesco Perono Cacciafoco ${ }^{(\mathbb{D})}$ and Francesco Cavallaro * \\ Linguistics and Multilingual Studies, School of Humanities, Nanyang Technological University, \\ Singapore 637332, Singapore; fcacciafoco@ntu.edu.sg \\ * Correspondence: cfcavallaro@ntu.edu.sg; Tel.: +65-65921710
}

Received: 8 June 2018; Accepted: 4 July 2018; Published: 7 July 2018

\begin{abstract}
This paper recounts a parallel story of the Lamoling myth. The original analysis of the legend addressed the relationship between two gods, Lamòling and Lahatàla, from the Abui traditional religion. The myth evolved from ancestral times to the arrival of Christianity in Alor, with the resultant association of the 'bad' god as a demon and, finally, as the devil. This paper completes the myth as handed down from traditional 'owners' of the narrative and storytellers by telling a parallel version centered around an Abui 'prophet', Fanny, who was the only person able to travel to Lamòling Bèaka, 'the land of the Lamòling gods/servants'. We also focus on a number of sacred objects and rituals associated with this religious myth and on their symbolic meaning for the Abui. This account tells a different version of the killing and eating of an Abui child by these gods/supernatural entities and of how Fanny came upon the gruesome feast. The paradoxical absence of Lamòling in this version of the myth depicts him as an immanent being, pervading and sustaining all that is real and created in nature, existing anywhere and nowhere at the same time.
\end{abstract}

Keywords: Abui; Alor; Lamòling; Alor-Pantar Archipelago; oral legends and myths; traditional religions

\section{Introduction}

This paper presents a parallel version and, therefore, a completion of an Abui oral legend, the Lamoling founding myth. The original version was analysed (Perono Cacciafoco and Cavallaro 2017) in the context of it being the origin and explanation for a number of toponyms and micro-toponyms still existing in the Abui territory on the island of Alor (South-East Indonesia, Alor-Pantar Archipelago) shown in Figure 1. Right up to today, the Abui believe that the tale of Lamoling is true and they claim that it is a historical episode dating to before the arrival of the Portuguese and Dutch colonizers and, therefore, concurrent with the arrival of Christianity. In this article, besides the reconstruction of a parallel (still unpublished) version of the legend, we focus on a number of sacred objects and rituals associated with this religious myth and on their symbolic meaning for the Abui.

Abui (ISO 639-3: abz; Glottolog: abui1241) is a Papuan language (Trans-New Guinea family, Alor-Pantar sub-family) spoken by around 17,000 speakers in the central part of Alor, South-East Indonesia, Timor area (Kratochvíl 2007; Klamer 2014, pp. 5-53). The local name for the language is Abui tangà, which literally means 'language of the mountain'. The Alor-Pantar languages are a set of related Papuan languages spoken on a number of islands in the Alor Archipelago (Figure 2). 


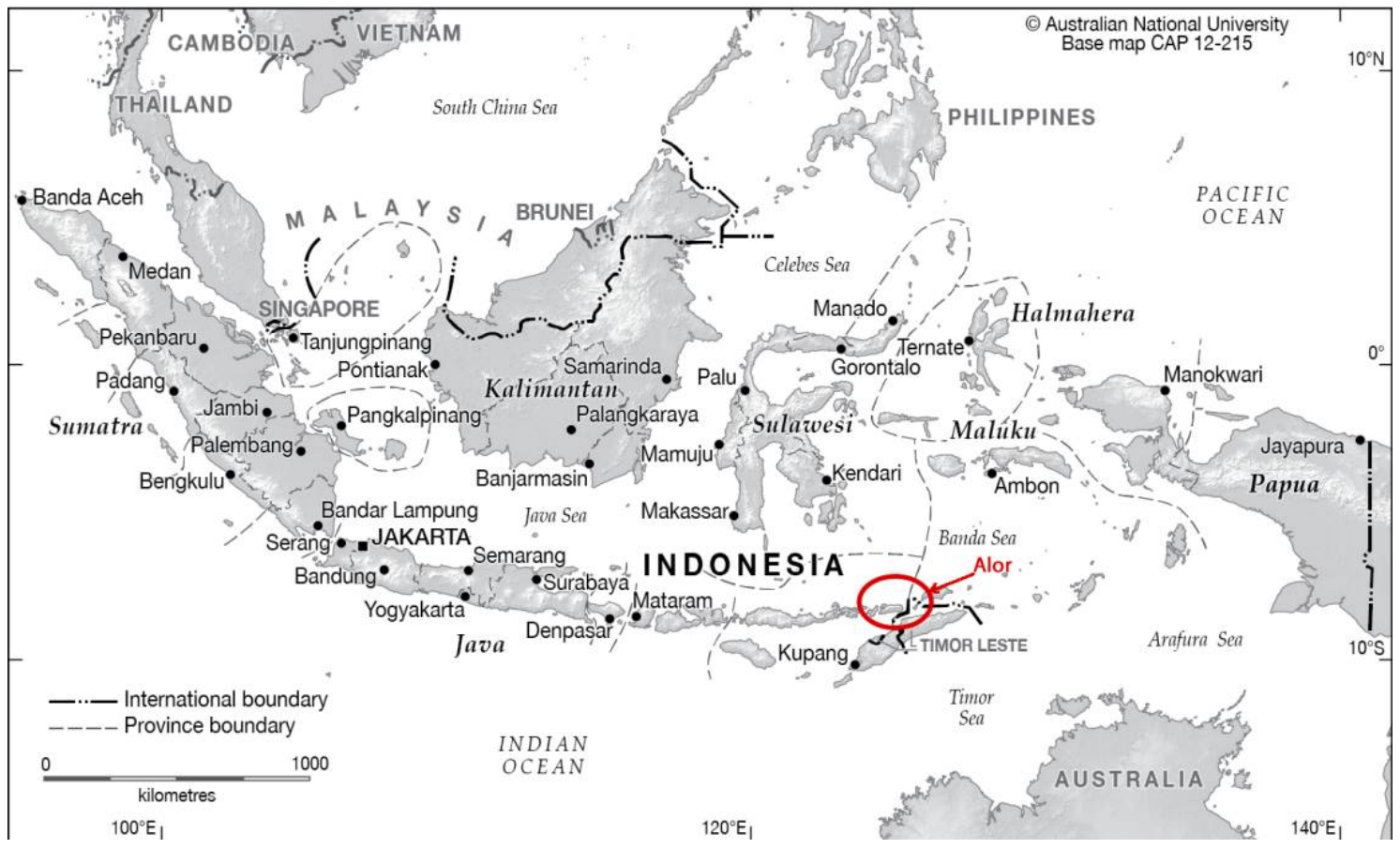

Figure 1. Location of Alor (Source: CartoGIS Services, College of Asia and the Pacific, The Australian National University).

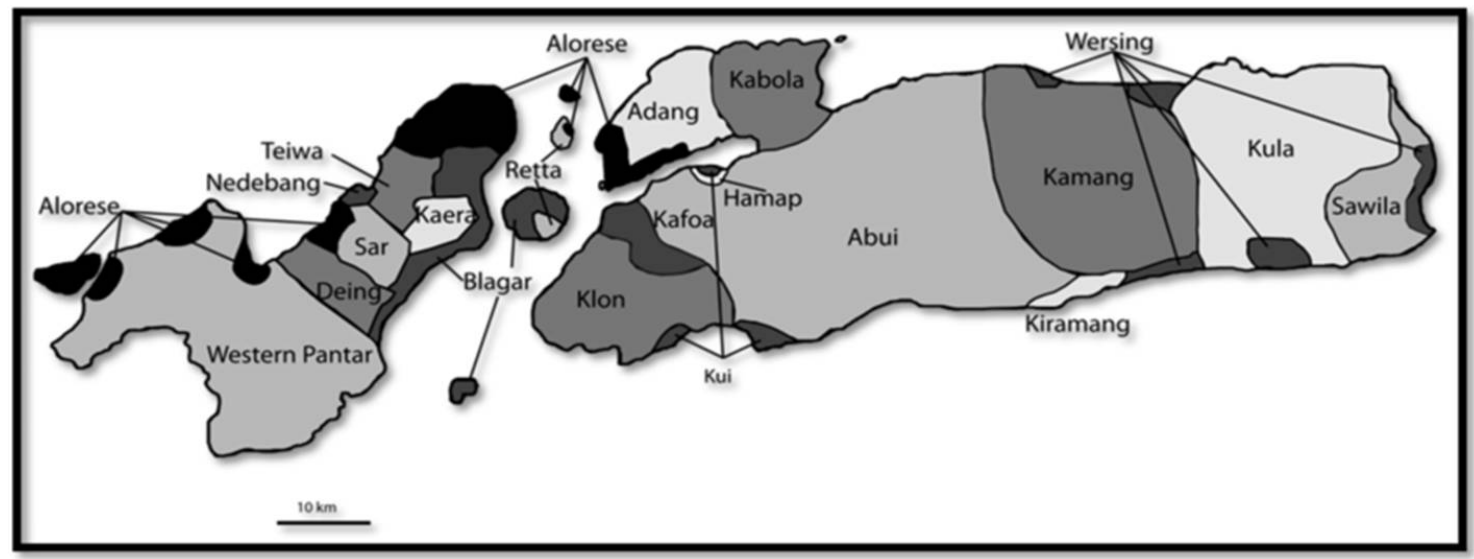

Figure 2. A linguistic map of the island of Alor and its neighbour Pantar (Source: Robinson 2015, p. 20).

\section{Oral Traditions among the Abui}

The legend of Lamòing was recorded and reconstructed during a period of language documentation fieldwork conducted in Alor by one of the authors (1 June 2015-10 June 2015). The main Abui villages involved in this linguistic investigation are Takalelàng and Takpàla, located in the Northern coastal area of Alor. Six other places, villages and areas of those villages, are involved in the story (Perono Cacciafoco and Cavallaro 2017, p. 59). The tale was told by a number of local storytellers. The story, in all its versions, was recounted in Abui and translated with the help of local informants. Traditionally, among the Abui, only the 'owner' of a story knows the full version and is authorized to tell it in its entirety, both to the local 'audience' and to individuals not belonging to the community. Other people who have heard the story from the 'owner' are allowed to recount it, but are only authorized to tell an abridged version of it and not the full story or specific details. The story and the plot of the story are not taboo in themselves. 
This custom is akin to the anthropological concept of the 'Big Man' (Sahlins 1963). The similarities between the 'Big Man' and the Abui story owner lie in the fact that, for the Abui, the owner of the story is also the 'moral owner' of all the land and villages that are part of the story. So, for example, if a man wants to marry a woman from another village, and both the villages are included in a story, they need to ask permission to wed from the owner of the story. Or, if some people want to build a house in one of the villages in the story, then they have to ask permission to do so from the owner of the story. A notable example of this notion of the 'ownership' of oral traditional stories can be seen in the Abui history of the recounting of the giant snake, Mon Mot, another founding myth belonging to the Abui people. Researchers carrying out language documentation fieldwork in Alor in 2003 first reported the story of Mon Mot as it was narrated by Anderias Padafani, and thought it was the complete version. However, over time, they came to be aware of the practice of the 'ownership' of the oral stories (or the 'Big Man' tradition) among the Abui and realized that the story they had was not the full version of the original legend. It took researchers 11 years to finally track down the true owner of the story, Mansur Maata (Kratochvíl and Delpada 2008, pp. 68-77).

We do not know who the original owner of any Abui story was. These stories are ancient. We assume that the original, first owner may be the one who first told or 'invented' the story. It may also have been someone involved in the 'real events' of the story, since, generally, a legend is not a completely invented tale, but derives from possibly real and very ancient events (Tangherlini 1990, pp. 371-90). The next owner of a story is chosen by the previous owner. The transmission is not necessarily within the family of the owner. The owner is chosen because of her/his moral qualities and because of her/his potential as a moral leader. Of course, the owner can be also a child of the previous owner, but there may not be a 'family lineage' in the ownership.

The Abui 'owner' of the original Lamoling myth (the widespread, complete, version) is Markus Lema, connected with the Delpada family, which shares and passes down that version generation by generation. Moreover, the 'owner' of the parallel version (the 'immanent' one) has always been a member of the Delpada family, with the current owner being Martinus Delpada.

Like for most indigenous oral rituals and cults, there are no written records of Abui traditional religion. Unlike, among others, Christianity and Islam, which have records dating back hundreds of years, the Abui only have songs, sayings, proverbs, and stories passed down as oral traditions generation by generation, over centuries. One of the aims of the present paper is, indeed, to preserve this noteworthy (and threatened) part of the Abui tradition and oral culture.

Due to the complex 'ownership' system among the Abui, that is, the fact that only the true 'owner' of the story can tell it in its entirety, with all the details, and with all the names of characters and places, the legend of Lamòling exhibits various inconsistencies and different 'chronological' layers and developments that compose a sort of 'stratigraphy of the myth' (Perono Cacciafoco and Cavallaro 2017, pp. 52-53 and 58). However, these 'anomalies' in the fabula of the legend do not detract from the story itself, but authenticate it as a real and coherent oral tradition. Contradictions and inconsistencies (Lord 1938), or variations and embellishments (Finnegan 1992), have been an accepted and often debated characteristic of oral traditions all over the world and in different diachronic contexts, from the Homeric epos to the oral myths of Africa and Australian Aboriginal people. Indeed, a 'fixed' story can only be found in written texts and, even then (both in oral traditions 'standardized' by being transcribed at a specific point in time and in stories originally written), examples of contradictions and inconsistencies are not rare (Lord 1938). Foley (1991) takes this one step further and argues that what readers of a text may consider gaps in a story as flaws are not flaws in the context of the orally transmitted stories: "For if we understand that a literary reception of an oral traditional text (whether unambiguously oral or oral-derived) must by its very nature fail to bridge all of the gaps of indeterminacy in anything approaching a way faithful to the aesthetic reality of the work, then we shall see that calling these gaps 'flaws' is itself a mistake" (p. 47). 


\section{The Lamòling Myth}

The Lamoling legend is a founding myth (Campbell 1976, 1990) centred on the opposition, or dichotomy, between the ancient (originally animistic) primordial god, Lamòling, who was also seen as a friend by the Abui people, and the 'new' god Lahatàla, who ultimately usurped Lamòling's place at the head of Abui's hierarchy of gods and, eventually, became the personification of the God of the 'new' Abui Christian faith (introduced by Western missionaries from around the XVI century) (Aritonang and Steenbrink 2008; Schröter 2011), the 'only and true God'. Semantically, we can see that the name Lamoling has gone through distinct changes, over time, in the Abui language. The name began being associated with the mightiest of local 'gods' (perhaps the 'best' of local gods and the one more connected with humans). Then, it changed slowly to refer to a 'demon'. With the arrival of the rival character in this religious dichotomy, Lahatàla, the 'other god' (then become 'the only and true God' of the Christian tradition), Lamòling became the personification of the 'devil'.

Some of the intrinsic characteristics of the figure of Lamoling contributed in 'making' this change. The Lamòing that the Abui identified with was a trickster deity, deeply connected with human beings, but also living in a dimension beyond the understanding of humans (being a god), and becoming, sometimes, a terrible punisher beyond human rationality (Perono Cacciafoco and Cavallaro 2017, pp. 51, 53, 55, 57, and 58). In this, Lamòling could be identified with other figures (from other religious contexts) of very important deities who were also tricksters, connected with the humans, but 'located' in a dimension oriented beyond the human understanding (a 'feature' foreshadowing the primordiality of these gods), like Dionysus/Bacchus (in Ancient Greek and Roman traditions), Loki (in Old Norse tradition), and, to some extent, Kokopelli (in Native American traditions) (Perono Cacciafoco and Cavallaro 2017, pp. 52, 55, and 58).

The original or more ancient story (its 'core', coming directly from the mythopoesis process) can be identified, therefore, in the earlier period of the tale, when Lamòling was the main god and had a friendly and continuous relationship with the Abui people. Lahatàla only makes an appearance later in the story (as a very spiritual god, living in the sky, not assuming anthropomorphous appearance, and entering the body of individuals in order to communicate with the Abui people), if we consider the story itself composed of several diachronic 'layers' (the aforementioned 'stratigraphy of the myth'). Before the arrival of Europeans (and, with them, Christianity), and in the early days of European contact, the two gods coexisted for a while, both worshiped by the Abui people (Lamoling as the god 'friend' of Abui people, Lahatàla as the transcendent and less 'humanized' god), until Lahatàla supplanted Lamòling (telling the Abui that he was 'the only and true God' - the 'Christian God'—and that the Abui people had to stop worshiping Lamòling and all other deities but Him). The coming of the new god represents the more modern part of the tale, foreshadowing the introduction and, then, the spread of Christianity in Alor and in the Abui community. Historically, as mentioned, this happened with the arrival of the Portuguese and Dutch colonizers and their missionaries, beginning from the XVI century (Aritonang and Steenbrink 2008, especially Chapter 4). To this day, the Abui are still mostly Christian.

The story goes that Lamoling and the Abui people lived often together side-by-side. The ancestral god seemed to prefer living among the humans over in the supernatural world. Lamoling spent his time with the Abui people and shared their everyday life events. He danced with them. He dined with them and taught them many things, including arts and crafts, introducing technology and music to them. The Abui people had a sacred place for them to meet with Lamòling, called Karilik. During the meetings with the god, the Abui people danced a ritual dance, called lego lego dance (discussed below). At that time and for a long time, Lamòing was seen as a benevolent god. However, something happened to change this relationship. Lamòing showed a dark side of his character that the Abui were not aware of (the 'irrational' side proper of atavistic deities like the aforementioned Dionysus and Loki). This happened at the time that Lahatàla, the 'alternative' and 'transcendent' god, made his appearance. At that time, Lahatàla lived in the sky, being a more metaphysical presence than Lamòling. At one point, though, Lahatàla started to meet the Abui people more and more often, becoming part of 
their lives, without ever showing himself, but always entering the bodies of people and speaking to the Abui through them. The two gods lived side-by-side, apparently peacefully. However, the change in relationship between the Abui and Lahatàla became a source of jealousy for Lamòling.

One characteristic of Lamòling was that he could take on animalistic and anthropomorphic shapes. The original animal-appearance of Lamoling was that of a python, characterizing him as a primordial chthonic god. Indeed, he could change himself into different animals, especially the snake, a very typical and widespread hypostasis of chthonic deities, or even a human being. He had a number of minor deities as his servants, who could also do the same, although, not being as powerful as he was, they were able to assume only shapes of various animals. Lahatàla, instead, was more of a pure spirit, a transcendent god who did not want to show himself and used to enter human bodies of local individuals in order to talk to the Abui only for very important communications. We are not aware of the Abui believing in 'spirit possession' (Laycock 2015). There are no traces of that in other records or tales that we have come across. In this case, Lahatàla enters the bodies of people merely to talk, and only on special occasions (he just 'talks' through them and does not 'force' them into any other act). It is difficult, therefore, to see this aspect as a spirit possession in a classical form. It seems merely a way for Lahatàla to 'contact' the Abui.

One day, the Abui people organised a party to celebrate both Lamòling and Lahatàla and their valuable friendship with the humans. The gods and lesser gods were all present, and they all drank and danced together (all but Lahatàla, who was attending the party as a transcendent spirit). The story tells how, sometime during this party, Lahatàla entered the body of a woman and told the Abui people that Lamòling was not a good god and that they would have had to end their relationship with him. No Abui would have to worship Lamoling anymore. He instructed them that Karilik would become the sacred place only for him and used for his meetings with the Abui people only, excluding Lamòling. He also told them that he would remain with them forever as their 'only and true God' (the Biblical references of this part of the story are evident). The Abui people were very impressed by the power of Lahatàla and accepted his 'conditions'. However, Lamòling found out or heard of this conversation and he was not happy, even if he pretended that nothing had happened.

As the evening unfolded, something terrible transpired. An Abui child went missing. The reason why is not apparent. The story tells of a very jealous Lamoling out for revenge on what he deemed a betrayal by the Abui people. The Abui people, naively, had no reason to think anything sinister had happened because of the party and went looking for the missing child, thinking it was lost on the way to the village. Their search took them from the very steep hill where Takalelàng and Takpàla are located towards the coast. On the way to the coast, a group of searchers passed through a place normally used by Lamoling to rest or meet with the Abui people on some occasions. At that time, that place did not have a name, since it was not properly a 'specific' place, but just an 'intermediate point' on the road between the villages and the coast. Upon reaching the place, the Abui met some of Lamoling's servants who were in animalistic form. These servants invited the Abui to join them for dinner. On sitting down for supper, the Abui were horrified to see that the food offered to them was actually the dismembered body of the missing child, including the head, which was placed in the middle of the table. Being mere mortals and surrounded by minor deities, they could do nothing. They partook of the food offered, but did not eat the meat. When they took their leave, they asked whether they could take the head of the child back to the villages to eat later, cooked with potato leaves, and to share with the other Abui people. They were given the head quite readily, which they took back to the villages. From that day on, that place, where the gruesome dinner took place, was known as Lamòling Bèaka, 'Lamòling bad/cruel', and it is from that episode that it got its name.

The enraged Abui immediately began to plan their revenge. They exacted their vengeance by organising another party, to which they invited Lamoling and all his servants. From here, we can start to see the downward spiral of Lamoling from 'god' to the status of a demon with his servants as minor demons themselves. The party went on for days, with lots of food, dancing, and drinking. The plan worked, as all the demons became tired and fell asleep. The Abui people, then, locked and 
boarded up the house where the party took place and set it on fire. All the demons burned to death. Lamoling, however, was only pretending to sleep and, changing into the semblance of a pregnant woman, managed to escape.

On that day, Lamoling completed his descent from the status of god, to demon, to the devil. Lahatàla, conversely, became the 'only and true God'. The legend shows a 'vertical' passage of diachronic layers from an animistic context (with Lamòling and his servants as the representation of chthonic, primordial entities), to a sort of polytheistic-mainly dichotomous-context (with Lamòling, Lahatàla, and minor deities), to a monotheistic context where Lahatàla is the 'only and true God' (the Christian God) and the other 'original god' (Lamòling) has become the devil.

The roles of Lamòling and Lahatàla can be summarized as the scheme below (from Perono Cacciafoco and Cavallaro 2017, p. 58).

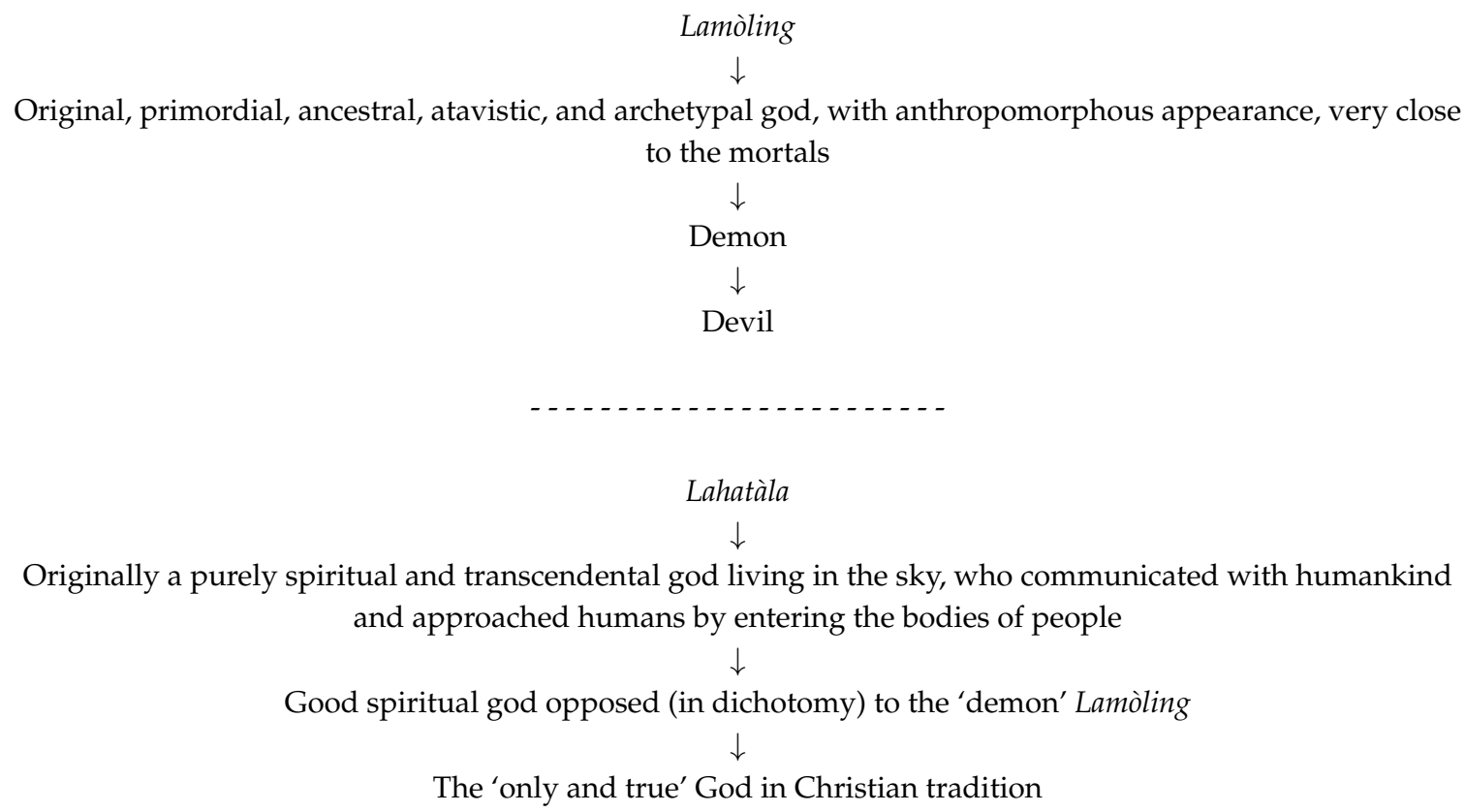

There are a number of slightly different versions of the story, which enrich the 'standard' plot and which are added to the 'official' version 'owned' by the Abui 'Big Man' in a juxtaposition. With the arrival of Christianity in Alor, the story became 'fixed' in the version that depicts Lamoling as the 'devil', and the opposition of Lamòling and Lahatàla became that of the devil versus the 'only and true God' in Christian terms.

The unpublished variant of the story we are recounting in this article is one of the more important and original versions we were able to acquire.

\section{The Prophet Fanny's Story and Lamòling Bèaka}

An Abui man called Fanny, who, according to our informants, really did exist around two generations ago, from Takalelàng, was said to have been able to live in two words: the real one and the supernatural one. He was the only Abui to be able to go between the two worlds freely. Fanny was recognized by the Abui people as a 'prophet' not because he was able to predict events, but because he was connected with the story of Atèng Afèng. This is the name of the mythically original Abui village from where, according to the Abui tradition, the Abui people first came into being. The story of this village is another sacred Abui founding myth (indeed, the myth about the ancestral origins of Abui people), and no one in the Abui community (apart from the 'owner' of the story, so far not found) is allowed to tell it in its entirety. The little details we were able to get from those that had heard the story are full of Biblical references, and the legend seems to be about a couple who gave birth to seven children (a clear reference to the seven sons of Japheth in the Bible, Book of Genesis), who founded the 
Abui village, and all Abui are descended from them. There is no precise documentation of this story and, so far, it has been impossible to find the related storyteller/'owner'. Fanny was supposed to be the only one who knew the full story, being, in a way, the 'owner' of that sacred founding myth and a sort of 'proto-storyteller' (or 'principal storyteller') of the community. The specific word 'prophet', if applied to Fanny, could be considered 'improper'. However, the Abui define the character this way and we'll keep this term to describe him.

Fanny, indeed, was not properly a 'prophet', but a man with a pure heart and whose eyes were as innocent as those of a very young child. Most Abui use the name Fanny as a nick-name (or abbreviation) for children called Franciscus. Fanny, indeed, was named after Saint Francis of Assisi (San Francesco d'Assisi, in Italian, Sanctus Franciscus Assisiensis, in Latin, 1181-1226). Fanny is considered, in Abui folklore, as an individual able to live in both the real world and the supernatural world. He is not a 'prophet' and, much less, a shaman. His innocence and purity allow him to travel from the real world and to meet the local gods/entities in the supernatural world. In this version of the story, it is the supernatural world that goes by the name Lamòling Bèaka. Before the horrible and gruesome act of killing the child and eating his meat was committed, that place had no name and there were no connotations (good or bad) attached to its location. In the original version of the story, the name was given to the real physical place where the child was killed, after the fact. The place was just a nameless location between the villages of Takpàla and Takalelàng and the coast, nothing else. In this version, Lamòling Bèaka is also the name of the supernatural world, a parallel world accessible only through the 'gate' of pure eyes. Lamòing Bèaka is the land—or the 'kingdom'—of the Lamòlings (see below) and, at the same time, the 'entrance' of that land. These Lamolings were, according to the variant of the story, supernatural creatures, beyond the human laws and understanding, substantiated by the 'soul' of Lamòling, a god so 'transcendent' and 'imperceptible' (but substantiating of himself all things and the creation) to become a purely immanent deity (he is nowhere, but he is in everyone and in everything, anywhere). Fanny lived with the Abui people, in the common physical world, and also in the supernatural metaphysical world, fraternizing with the supernatural beings, the 'Lamòlings', entities which were emanation of the 'anima mundi' Lamòling.

This version follows the original story until the kidnapping and killing of the child. However, this variant does not depict Lamòling as a 'single god' (as the Lamòling of the widespread version), but takes the 'Lamòlings', his servants, as the representation/emanation of Lamòling himself. The legend seems more precise in describing the figure of the child, telling of the day when an Abui woman and her young son went down to the beach, from Takalelàng, in order to collect shells. That happened at the same time of the 'replacement' of Lamoling (as an immanent god, or of the 'Lamolings' as his emanation, in this version) with Lahatàla in the Abui religion. Coming back to the village, the woman was faster than the child. He lagged behind and was soon out of his mother's sight. The child started crying as he made his way slowly up the mountain path. While he was walking and crying, he arrived at Lamòling Bèaka and, his eyes being pure, passed from the real world to the supernatural world of Lamòling's gods/entities. According to the Abui, those Lamòling deities could look at normal people, without being seen, interacting with them without people being able to notice their actions (unless they wanted to show themselves). They lived in a parallel world linked to the real world and were able to act in both of them. The child's innocence had allowed him to involuntarily cross between the two worlds and reach Lamòling Bèaka and, because of that, his destiny was sealed. The inhabitants of Lamòling Bèaka were supernatural entities and their behavior was beyond human laws, understanding, rationality, and beliefs. The beings in Lamòling Bèaka were indeed very happy to see the child and said: "Here, our grasshopper has come" (Abui people used to eat grasshoppers as a source of proteins). They killed him and cut his body in small parts in order to cook and eat them.

By this time, the mother had reached the village and reported that her son was missing. The Abui people looked everywhere for him, both on the mountains and at the seashore, village by village. However, they were unable to find him. They consequently asked Fanny to help them. The 'prophet' went out searching for the child, without knowing that the child had already been killed. Looking for 
him, Fanny, as was his habit, crossed into the supernatural world, Lamòling Bèaka, thinking he would be able to get some help from the 'Lamolings'. They, as a sign of hospitality, asked him to join them for dinner and offered him meat to eat. The man immediately noticed that it was human meat and he understood that it was the body of the missing child. He did not do anything that would reveal his horror and his pain. He simply told them he was in a hurry at that time and asked them to give him the head of the child in order to bring it back to the villages, to cook it later with potato leaves. "Please give me the head of the meal, so that I can bring it back to the villages and cook it to be eaten with potato leaves", were his words. The 'Lamolings' gave him the head, which he was able to bring to the villages, to organize a funeral. This way, the villagers discovered the truth. Since only Fanny was able to travel to the supernatural world, the Abui people were unable to go to Lamoling Bèaka to exact their revenge. So, they set their vengeance to take place in a village north of Takalelàng and Takpàla, Lù Melàng ('the village of the river'; in Abui, lù is 'river' and melàng is 'village'), currently abandoned, a place considered as the original 'house' of the Delpada family of Takalelàng and Takpàla.

From here, the story continues almost uniformly in both versions, but with the very significant variant and/or inconsistency of the absence of Lamoling in the second one. In the second version, the 'Lamoings' are burned in the wooden house, and the Abui people are able to get their revenge, but Lamoling does not attend the party, never appearing (since he never appears, in this variant of the story, being a purely immanent deity). He does not change himself into a pregnant woman, nor does he need to escape, since he is not there or, better, he is 'also' there, since he is considered the entity substantiating not only the 'Lamolings', but all of creation. Paradoxically, also the Abui people who burn the 'Lamolings' are substantiated by Lamòling, who appears, as mentioned, a sort of Platonic (Plato, Timaeus, VI, 30b-30c) and Neo-Platonic (Plotinus, Enneads, IV, 4, 32) anima mundi $(\psi v \chi \eta \dot{\eta} \kappa \sigma \mu \nu v)$, the principle at the origins of all the 'items' in the world, pervading them of its essence. The notion of this 'soul' that makes and keeps stable the world is also common in Hinduism with the concept of 'universal soul', often identified with the Átman, the principle of the individual and inner 'self', inextricably joined with the Brahman, the principle of the outer world (Werner 2005, pp. 10 and 58). In the West, the Neo-Platonic tradition of the notion of anima mundi was continued, in the Humanism and Renaissance times, by Marsilio Ficino (1433-1499) and Giovanni Pico della Mirandola (1463-1494). The XVI century had in the work of Giordano Bruno (1548-1600) the most important representation of the anima mundi intended as pure immanentism, with the identification of God and Nature (the so-called Pantheism, 'All is God'), emblematized by the famous sentence attributed to Baruch Spinoza (1632-1677), Deus sive Natura ('God or The Nature') (Picton 1905). The Neo-Platonic idea of an immanent god identified with Nature has also been recovered, in the Romantic age, by Friedrich Schelling (1775-1854) (Grant 2010).

After the burning of the 'Lamolings', the Abui people abandoned the primordial religion of gods and entities, the 'emanation' of the immanent anima mundi Lamòling, to exclusively worship the transcendent 'only and true God' (the Christian God), Lahatàla.

Both the versions of the story identify Lamoling as the one responsible for the taking and killing of the child, even though in the first variant Lamoling himself does not appear as the kidnapper and the killer (the action is accomplished by his servants, apparently) and in the second version Lamoling is a purely immanent god who does not act directly in the world, since he completely substantiates it.

According to Loisa Delpada (a member of the Delpada family from Takalelàng and, originally, from Lù Melàng), after Fanny passed away, his burial place rolled inside the river Kanaài Loohù because of a flood, as if Nature wanted to take the 'prophet' again within itself (in a sort of cosmic Panism or Naturism). However, people were able to recover his body. Another version tells of his wooden coffin taken away during a flood, but directly returned by the river, which carried it uphill against the flow of the current (the water reversed its course) to his final resting place. The belief of the Abui is that he was dear to the creator and all mighty God, although they do not know if that god was the Christian God, Lahatàla. However, since his story is entwined with that of Lamòling, it could be possible that he (the forsaken god) saved his body from the flood. 


\section{Comparing the Two Versions}

The main difference between the two accounts is the paradoxical absence of Lamòling himself in the second version of the myth. The original story tells us that Lamoing is a god who is 'real' in every sense, materially, with his ability and penchant to take on animal or human forms and physically consorting with his followers and believers, and metaphysically, in that he is their god and is worshipped as such. Lamòling is a more 'human' (or 'humanized') god than a transcendent god like Lahatàla, and spends most of his time with the humans. The second version, conversely, has no mention of him, even if the speakers/storytellers 'know' that Lamoling is 'there' and exists, since they interpret him as the 'soul' originating and substantiating the world and also the 'Lamolings' and the humans. The place where his 'servant gods' meet bears his name and even these 'servant gods' do not have an individual name, but carry his name all together. The Abui refer to them, indeed, as the 'Lamòlings'. This version depicts Lamòling as an immanent being, pervading and sustaining all that is real and created in nature.

\section{Abui Traditional Concept of Religion}

The Abui religion and culture was originally characterized by animistic and, then, polytheistic beliefs. Nowadays, the majority of the communities in Alor Island are Christians. They are predominantly Protestant, with some Catholic groups. More recently, significant numbers of Muslims have migrated to coastal areas in Alor from neighbouring islands (Kratochvíl 2007; Rodemeier 2010, pp. 27-42). The legend of Lamòling is the mythical description of people's passage to a monotheistic creed, Christianity (characterized by the figure of Lahatàla, the Christian God introduced in Alor by Western missionaries) (Perono Cacciafoco and Cavallaro 2017).

Little is known or written about the Abui earlier animistic practices. Their polytheistic beliefs can be discerned, among others, from the legend of Lamoling, when we consider the coexistence of Lamòling and Lahatàla, and the fact that the 'servants' of Lamòling are always referred to as some types of deities at first and, later, as demons, although none of these lesser deities have individual names in any version of the legend. In fact, also in the second variant, they are only known through the collective name 'Lamolings', derived from the name of the main god. This points not to a pantheon of gods, as this implies a pluralism that is not apparent in historical data or in the legend, but to a possible polytheistic order, also foreshadowed by other legends where other gods appear, like the aforementioned giant snake Mon Mot (even though it is unclear if the snake could be defined 'a god' in the proper sense of the word or if he could rather be a hypostasis of natural violent and catastrophic phenomena). However, this context cannot be considered polytheism in the classic sense, as here the gods are not independent from each other or have in any way equal status and power. This polytheism has, apparently, a strict hierarchy, with Lamòling originally at the head. Negedu (2014) says of the Igala in Nigeria: "This understanding of the concept of polytheism justifies the claim of the Igala in monotheism, since what appears to be many is just a hierarchy of supernatural beings." (p. 123). Just like Igala's god, Lamòing is not on the same level as all the other deities around him. He is the Supreme Being and is beyond the realm of what is known by the Abui people. Lahatàla is a later addition that does not affect the original interpretation of the Lamoling figure.

Both stories show how Lamòling was regarded as, possibly, the creator of all things. He was connected with the origins of life and the guarantor of man's actions on this world. According to the widespread version, he displayed his anthropomorphic attributes by walking the real world in an animal form (originally the snake, as discussed above, a typical and universal hypostasis of chthonic deities) or human form, as did his entourage of lesser deities (only in animal form). In the second version, he is, instead, above all beings, including his pantheon of lesser deities, and, in his absence, reminds us that his immanence is also, to some extent, transcendent. It is complicated, indeed, to understand, in the second version, if Lamoling is a purely immanent god (as he seems to be, in any case) or if, besides generating and substantiating the world (immanence), he also tacitly spreads his action in the creation (transcendence). The two contrasting variants make it difficult to understand 
to what extent Lamòling is involved with the Abui people, what is his 'real' relation to the humans in the widespread version and if he has part in the actions of the second version. When speaking about West African religions, O'Connell (1962) put forth the concept that these religions " [ ... ] have a high-god who is also a sky-god. But he is often a withdrawn high god, a deus otiosus. There is an apparent contradiction between the supremacy of the high-god and his withdrawal from concern with the world" (p. 67). Is Lamòling, in the second version of his legend, purely an anima mundi or, rather, a deus otiosus ('idle god'), delegating the actions in the world to natural spirits or intermediate entities? An example of deus otiosus is given by the notion of "first unmoved mover", the primum movens ( $(\hat{o}$ o $\kappa l v o v \mu \varepsilon v o v \kappa l v \varepsilon \tilde{l}$, 'that which moves without being moved') by Aristotle (Metaphysics, XII, 1072a). Lamòling could also (and/or better) be identified with the notion of deus absconditus ('hidden god'), originally theorized by Saint Thomas Aquinas (1225-1274), but developed, in the context of apophatic theology (or negative theology), by Nicolaus Cusanus (1401-1464) (Belzen and Geels 2003, pp. 84-87). The deus otiosus, indeed, could be intended as a god who has created the world, but does not want to be involved in it anymore, and who is often replaced by not original, lesser gods. The deus absconditus, conversely, is a god who has consciously left this world, after giving shape to it, to hide elsewhere, closed in his perfection (Eliade 1978).

\section{Objects, Places, and Rituals}

Lamòling Bèaka became for Abui people a sacred place linked inextricably to this story. In the original telling, the name was given to the (real) place where the horrific dinner occurred after the death of the child. This place was also the venue for the meetings of Lamoling with his servants. In the other version, the place had always existed as a sort of 'portal' to the supernatural world (the world of the 'Lamòlings', entities who were direct emanation of the anima mundi Lamòling). Only children with very pure eyes were able to (involuntarily) enter the 'portal'. Fanny, being pure in his heart like a child, was the only adult Abui able to cross over to the other world. The place, being not a 'human' place, but a 'gate' to the supernatural world, did not have a name (since Abui people-apart from Fanny-did not perceive it as a significant place). It was, apparently, just an 'intermediate point' in the route from the villages of Takpàla and Takalelàng to the coast. After the child was killed, the place itself (the 'real' and 'physical' place) was called Lamòling Bèaka, meaning 'Lamòling the bad/evil'. The toponym, after Fanny (crossing the border between the physical world and the metaphysical world) discovered the terrible action committed by the 'Lamolings', referred to the place in both the real and the supernatural worlds. The place became part of the traditional religion of Abui people, inextricably connected with the Lamòling myth.

There are a number of other places that are associated with this legend. They appear in both versions. In the Takpàla village, two ritual houses, called Kolwàt ('the dark house') and Kanurwàt ('the bright house'), were (and are still) places of cult for Abui people and symbolize the passage from the 'old' ('dark') religion, the animistic and, then, polytheistic traditional Abui religion, to the 'new' ('bright') one, Christianity. The Kolwàt house, in the eastern part of Takpàla, is linked to the cult of Lamòling and is decorated with a geometric pattern symbolizing the primordial snake (the python), Lamòling. Kanurwàt, instead, is deeply characterized by a white geometric pattern, representing the ineffable and bright nature of Lahatàla

Karilik, the place in which (according to the widespread version of the story) Lamòing and Abui people met periodically (with an offer of food by the Abui to 'trigger' the arrival of the python/primordial god to eat with them at the Karilik altar and with the ritual lego lego dance), is located in front of the two ritual houses and is characterized by the presence of an altar with three ritual stones, symbolizing, according to the speakers, the skulls of enemies killed in war when Abui people were head-hunters. The micro-toponym Karilik derives from the cult of Lamòing and is traditionally associated with an offer of rice, being the name of the ritual karilik hè hàk, 'offer to the big old stones' (more popularly known by its shortened name, karilik) (Perono Cacciafoco and Cavallaro 2017, p. 53). These three flat stones are the cultic referents of the karilik ceremony. The Abui people would bring cooked rice to the ceremony. They 
placed the rice on the altar offering it, symbolically, to the gods (in particular, to Lamoling) through the three stones. Lamòling would have joined the ritual in the shape of a python. The rice was, then, eaten by those attending the ceremony — and, symbolically, also by Lamoling — establishing, through this sacred ritual, a connection with the god. In the original cult, the god joining the Abui people was Lamoling (probably, sometimes, with his lesser gods). It is difficult to establish if, at the origins, also other gods of the Abui people joined the ceremony. In the current versions of the story, the god joining the ritual with Abui people is Lamòling. Later, the Abui symbolically offered the rice also to Lahatàla, configured as a 'newer' god, as discussed earlier, who was more transcendental than Lamoling. Karilik was, therefore, the sacred name of the meeting venue of the Abui and Lamòing. Possibly, Karilik was also the place where the banquet hosted by the Abui set off Lamoling in his gruesome path and led to his abandoning by the Abui after Lahatàla told Abui people he was the 'only and true God' and they decided to worship only him. The original story says that Lamòling was angered by Lahatàla's instructions to the Abui to exclude Lamòling from the karilik and from all other rituals, and asking that Karilik be a place exclusively reserved for Lahatàla. This led to the anger of Lamòing and to the tragedy that followed. Altars with ritual stones are common in the traditional Abui inhabited centres, and they can also be found in currently abandoned Abui villages. As mentioned above, the stones could be, according to the local speakers, the 'representation' of the severed heads of enemies killed in war, when the Abui community was at war against other clans in Alor and when the Abui people were head-hunters. At least from the time of the introduction of Christianity in Alor, but, probably, also earlier, when a sort of 'diplomacy' was established among Papuan communities in Alor, the practice of exposing the heads of enemies killed in war was abandoned and stones were used in order to symbolize that specific past. Possibly, that is the reason of the 'power' of the stones, considered, by the Abui people, to be able to connect, during the karilik hè hàk ritual, the humans with the god Lamoling. So far, it has been impossible to document the names of the other altars with ritual stones (and of the related places) in other Abui villages.

The lego lego dance is a traditional ritual dance of Abui people, typical of the villages 'touched' by the story of the Mon Mot giant snake, including also (because of ties of kinship among Abui families) Takpàla and Takalelàng (Kratochvíl and Delpada 2008, pp. 68-77), and danced at the Karilik, in the Takpàla village, during the karilik hè hàk ritual, when Abui people shared their rice with Lamòling (and, then, with Lahatàla). Once, the Mon Mot snake, a primordial (but, paradoxically, mortal) god comparable to Lamòling, descended from the Alor mountains, killed almost all of the Abui people, and destroyed their villages. Only a woman was able to escape. She was pregnant and, hiding in a cave, gave birth to twins. When the kids grew up, their mother told them the story of Mon Mot and they decided to get their revenge. They prepared traps and weapons, and, then, they went to look for the snake, on the mountains. They found him, and they told him they were the only two survivors of the Abui people he had killed in the past. They challenged him to kill them as well. The snake started to hunt them and, when they reached the place with traps and weapons, the twins started to fight the snake. Nothing seemed able to stop him, but then the twins threw boiling oil in his mouth and the snake started to burn from the inside. He became weak and, despite being a god, he noticed he was dying. As he was dying, he told the twins that his life was in their hands and that he knew beforehand that they would have killed him. Calling them "my children", he added that, after his death, they would have to cut his body in parts of flesh and skin and they would have to distribute those body parts during the night in all the houses throughout all the villages he had destroyed, while killing all the Abui people. Then, they would have to dance the lego lego dance all over those places. The twins followed his instructions. After having killed him, they dismembered his body in parts of flesh and skin and they brought all those parts to the destroyed villages, putting them in the ground, house by house. Then, in the night, they started to dance the lego lego dance. As they were dancing, from the houses, Abui people killed years before by the snake started to come out, without any memory of having been killed, and joined the dance. All the Abui villages were suddenly populated again; the Abui people were back. 
The Mon Mot story is locally known as the Children of Mon Mot Legend, since the Abui people from the villages 'touched' by this ancestral tale believe to be (re-)born from the flesh and the skin of Mon Mot and to be, in a way, his 'descendants'. The Mon Mot legend is, indeed, a founding myth and the story shows points in common with other analogous myths in unrelated contexts. The legend of the god snake killing all people is a sort of variant of the flood myths widespread in a number of different cultures (Dundes 1988; Pleins 2010, p. 110). The same character of the snake can be considered as the representation of a natural catastrophe (a big snake descending from the mountains and destroying all the villages, killing all people, could, for example, foreshadow the eruption of a volcano in ancient times). The 'operation' to bring back to life the Abui people through the spreading of the body parts of the snake and the dance can be associated with the Ancient Greek founding myth of Deucalion and Pyrrha (Ovid, Metamorphoses, I, 327; Pseudo-Apollodorus, Library, I, 7, 2), who, being the only two survivors of the flood called upon by the gods to punish the corrupted humans (the myth of the flood is widespread among cultures, be it enough to think of the Biblical story from the Book of Genesis-Noah-and the flood myth-Utnapishtim-in the Epic of Gilgamesh), in order to populate again the world had to throw stones (the 'bones' of the Mother Earth, Gaia) over their shoulders. The stones gave birth to new people, with Pyrrha's stones becoming women and Deucalion's stones becoming men. The Abui legend adds the element of the sacred dance, the lego lego dance, which could be considered original. The dance, accompanied by chants with the value of spells, is the 'catalyst' of the (re-)generation of the Abui people from the parts of the body of the Mon Mot snake. The myth, as well as the story of Lamoling, is deeply connected with Abui genealogies and is used often by the Abui in order to establish kinship relationships among people and hierarchies in the 'antiquity' of family units among Abui clans.

The lego lego dance appears also in the Lamoling myth, danced at the site of the two Abui ritual and ceremonial houses, Kolwàt, 'the dark house', and Kanurwàt, 'the bright house', in the center of the Takpàla village, discussed above. The lego lego dance is usually performed not only during the karilik ritual, but also on the occasion of other religious and cultic ceremonies (Perono Cacciafoco and Cavallaro 2017, pp. 53-55).

\section{Transcendence and Immanence in the Lamòling Myth}

As mentioned above, the notion of immanentism in the Lamòling myth seems to be a product of the 'stratigraphy' of the Abui legend, residing in one of the 'sides' of the representation of this god. From animistic and, then, polytheistic origins, to a 'Christian interpretation', to a version where the god is possibly cause (origin) and principle (substance) of the world. The transcendence of Lamoling is different from Lahatàla's transcendence. However, in the widespread version of his myth, Lamòling is transcendent to the extent of being a god who belongs to both worlds, the 'real' one and the supernatural one, since it is he who decides to enter the 'real' world and to spend his time, often in anthropomorphic shape, among the Abui people. In the 'immanent' variant, Lamoling is a sort of anima mundi, or deus absconditus, probably cause (origin) of the creation and surely principle (substance) of the world. In a way, he is also 'transcendent', through the action of the 'Lamolings', his emanation (even though, by definition, all the 'items' of the world should be his emanation), on the world.

This dialectic between transcendence and immanence of the immanent divinity and the intelligible world (the creation) could find an interesting parallel in the second dialogue of De la causa, principio et uno (1584) by Giordano Bruno. In that work, Bruno starts his reasoning from the Pythagorean doctrine, describing the world soul (anima mundi) and universal intellect (voṽ $\varsigma$ )—a single entity, indeed—as immanent, position shared by the Neo-Platonic ontology ("The universal intellect is the intimate, most real, peculiar, and powerful part of the soul of the world", De la causa, principio et uno, II). This specific definition, in truth, derives, more precisely, from the Stoics, who defined 'immanence' as the 'world soul', while the Neo-Platonists considered it as a 'hypostasis soul', intermediary between the universal intellect and the physical reality (the world) (Knox 2013, pp. 465-77). Bruno, in his dialogue, adopted an originally Neo-Platonic distinction between the notions of 'cause' and 'principle', derived by the 
concepts outlined by Saint Thomas Aquinas in his De principiis naturae. The aim was to explain the simultaneous transcendence and immanence of the intelligible world. This philosophical issue was addressed by Bruno in the second book of De la causa (Knox 2013, pp. 477-81), and shows analogies with the representation of the divinity of Lamoling in the second variant of its legend in Abui oral culture and tradition.

\section{A Possible Etymology of the Lamoling Name}

The name of Lamoling could be connected, in the Abui language, with the word mòling, which indicates a specific part of the bride-price negotiation in Abui society, something needed to be paid for 'clearance' from a mother's obligation. That is, the daughter has to pay her mother before marrying to clear her mother's obligation. According to Benny Delpada (one of the consultants of our language documentation team and a member of the Delpada family from the Takalelàng and Takpàla villages), this 'mother's obligation' can be connected, as far as its mythical and traditional origins, with the mother of the killed child in the Lamòing story. It is possible, therefore, that Lamòling derives a section of his name from this part of his legend, plausibly the original core of the myth itself. It is also possible, in any case, the opposite option, that the word mòling derives from the name of Lamòling, since in Abui culture the onomatopoesis of 'common' words (and toponyms) in many cases originates from traditional stories. According to Benny, Lamòling could have been the surname of the child's mother. The name of Lamoling, therefore, could have been derived from her, starting to be used from this point of the legend. Our consultant does not know of any other name that the god would have had before this passage. As above, it is also possible that the surname Lamòling derives directly from the traditional story. Interestingly enough, Lamòling is still an attested Abui family name among local people, but not in Takalelàng, where it is considered inappropriate and also 'sinister'. Benny remembers a little girl attending middle school with him in Mebùng (4 km distant from Takalelàng, coming from Kalabàhi), whose surname was Lamòling. She was from Forlèng, located in the central Abui area, in Alor.

\section{Conclusions}

The impact and relevance of the Lamòling story, a founding myth in Abui religion, can be found not only in the consecration (and 'invention') of places (Karilik, Kolwàt, Kanurwàt, Lamòling Bèaka), rituals (karilik hè hàk, lego lego dance), and artefacts (the three ritual stones), but also in the close relation between Abui oral traditions and Abui original religion. By combining the two versions of the Lamòling story, we can highlight a significant and unexpected passage in the representation of Lamòling from a primordial god of animistic origins to a god inserted into a polytheistic context, then resolved in a monotheistic cult by the clash between Lamòling and Lahatàla in the original story, with the demonizing of the former and the deification of the latter, to an immanent context (in the alternative version), where Lamòing is a spirit comparable to the notions of anima mundi and deus absconditus, substantiating the world and all creation. Throughout the two versions of the story, Lamòling appears like a 'god among the humans' (in its anthropomorphic 'shape'), a transcendent god (less transcendent than Lahatàla, but transcendent by definition, since, even if he likes to live among the humans, he is a god acting in the world), and an immanent deity. The concept of the connection between transcendent and immanent and the joined representation of transcendence and immanence of gods in aboriginal contexts are not uncommon across the world, even if they appear according to many variants. Research in Africa (Metuh 1973; Ushe 2017), for example, has struggled with the question of whether African religions are purely anthropocentric, and the 'African god' is on the periphery of African world view. Talking about Igbo religion, Metuh concludes that "God in Igbo religion is at once transcendent and immanent. The transcendent God is the creator, the father of the Alusi, the consort of the Earth-Mother. The immanent God is the Supreme Spirit, who sends sparks of himself in the form of chi into men, natural phenomena, and things" (p. 9). The Lamòling myth, in its different versions, seems to share similarities with the Igbo paradigm. 
Our paper is the first record of the so far unpublished (and never documented before) second version on the Lamòling legend in Abui traditional religion. Besides highlighting a significant pattern in the development of the figure of the god from animistic origins, to polytheistic contexts, to the 'clash' with the introduction of a monotheistic religion (Christianity) in Abui culture, and to the representation of the god as an immanent entity, the paper analyses specific rituals, places of worship and objects. Moreover, as in our previous work on the widespread version of the Lamòling story (Perono Cacciafoco and Cavallaro 2017), this paper shows how, in Abui culture and religion, places are indissolubly connected with local myths, with the very significant link between mythopoesis and onomatopoesis in the coinage of specific place names (and micro-toponyms) after the local legends.

With the Lamoling myth having been recorded and collected during language documentation fieldwork, this paper is also a contribution to Field Linguistics and Anthropological Linguistics, with the aim to shed light on Abui traditional religion and culture and to help preserve the Abui language and oral intangible heritage and traditions.

Author Contributions: Conceptualization, Francesco Perono Cacciafoco and Francesco Cavallaro; Writing-original draft, Francesco Perono Cacciafoco and Francesco Cavallaro; Writing-review \& editing, Francesco Perono Cacciafoco and Francesco Cavallaro.

Funding: This work was supported by the AcRF Tier 1 Research Project RG56/14, Nanyang Technological University, Singapore.

Acknowledgments: We wish to acknowledge the two Abui native-speakers who recounted the story to us: Markus Lema and Darius Delpada, both from Takalelàng; and the Abui native-speaker who operated as an Abui-English translator/interpreter, Anselm Delpada, also from Takalelàng.

Conflicts of Interest: The authors declare no conflict of interest.

\section{References}

Aritonang, Jan Sihar, and Karel Adriaan Steenbrink, eds. 2008. A History of Christianity in Indonesia. Leiden and Boston: Brill.

Belzen, Jacob A., and Antoon Geels. 2003. Mysticism: A Variety of Psychological Perspectives. Amsterdam: Rodopi.

Campbell, Joseph. 1976. The Masks of God: Primitive Mythology. New York: Penguin.

Campbell, Joseph. 1990. Transformations of Myth through Time. New York: Harper Perennial.

Dundes, Alan, ed. 1988. The Flood Myth. Berkeley: University of California Press.

Eliade, Mircea. 1978. A History of Religious Ideas: From the Stone Age to the Eleusinian Mysteries. Chicago: The University of Chicago Press.

Finnegan, Ruth. 1992. Oral Poetry: Its Nature, Significance, and Social Context. Bloomington and Indianapolis: Indiana University Press.

Foley, John Miles. 1991. Immanent Art: From Structure to Meaning in Traditional Oral Epic. Bloomington and Indianapolis: Indiana University Press.

Grant, Iain Hamilton. 2010. F.W.J. Schelling, On the World Soul (Translation and Introduction). In Collapse VI: Geo/Philosophy. Edited by Mackay Robin. Falmouth: Urbanomic, pp. 58-95.

Klamer, Marian. 2014. The Alor-Pantar Languages: Linguistic Context, History, and Typology. In The Alor-Pantar Languages: History and Typology. Edited by Klamer Marian. Studies in Diversity Linguistics. Berlin: Language Science Press, pp. 5-53.

Knox, Dilwyn. 2013. Bruno: Immanence and Transcendence in De la causa, principio et uno, Dialogue II. Bruniana and Campanelliana 19: 463-82.

Kratochvíl, František. 2007. A Grammar of Abui: A Papuan Language of Alor. Utrecht: Landelijke Onderzoekschool Taalwetenschap (LOT).

Kratochvíl, František, and Benidiktus Delpada. 2008. Netanga neananra dei lohu naha: Abui tanga heateng ananra/Cerita-cerita dalam Bahasa Abui dari Takalelang/Abui Stories from Takalelàng. Leiden: Leiden University Press.

Laycock, Joseph P. 2015. Spirit Possession around the World: Possession, Communion, and Demon Expulsion across Cultures. Santa Barbara: ABC-CLIO.

Lord, Albert B. 1938. Homer and Huso II: Narrative Inconsistencies in Homer and Oral Poetry. Transactions and Proceedings of the American Philological Association 69: 439-45. [CrossRef] 
Metuh, Emefie E. 1973. The Supreme God in Igbo Life and Worship. Journal of Religion in Africa 5: 1-11. [CrossRef] Negedu, Isaiah Aduojo. 2014. The Igala Traditional Religious Belief System: Between Monotheism and Polytheism. OGIRISI: A New Journal of African Studies 10: 116-29. [CrossRef]

O'Connell, James. 1962. The Withdrawal of the High God in West African Religion: An Essay in Interpretation. Man: The Journal of the Royal Anthropological Institute 62: 67-69. [CrossRef]

Perono Cacciafoco, Francesco, and Francesco Cavallaro. 2017. The Legend of Lamòling: Unwritten Memories and Diachronic Toponymy through the Lens of an Abui Myth. Lingua: An International Review of General Linguistics 193: 51-61. [CrossRef]

Picton, James Allanson. 1905. Pantheism: Its Story and Significance. London: Constable.

Pleins, J. David. 2010. When the Great Abyss Opened: Classic and Contemporary Readings of Noah's Flood. New York: Oxford University Press.

Robinson, Laura C. 2015. The Alor-Pantar (Papuan) Languages and Austronesian Contact in East Nusantara. In Language Change in Austronesian Languages: Papers from 12-ICAL. Edited by Malcom D. Ross and I. Wayan Arka. Canberra: Asia-Pacific Linguistics, vol. 3, pp. 19-33.

Rodemeier, Susanne. 2010. Islam in the Protestant Environment of the Alor and Pantar Islands. Indonesia and the Malay World 38: 27-42. [CrossRef]

Sahlins, Marshall. 1963. Poor man, rich man, big man, chief: Political types in Melanesia and Polynesia. Comparative Studies in Society and History 5: 285-303. [CrossRef]

Schröter, Susanne, ed. 2011. Christianity in Indonesia: Perspectives of Power. Münster: LIT Verlag.

Tangherlini, Timothy R. 1990. "It happened not too far from here ... ": A survey of legend theory and characterization. Western Folklore 49: 371-90. [CrossRef]

Ushe, Mike Ushe. 2017. God, divinities, and ancestors in African traditional religious thought. Igwebuike: An African Journal of Arts and Humanities 3: 154-79.

Werner, Karel. 2005. A Popular Dictionary of Hinduism. New York: Routledge.

(C) 2018 by the authors. Licensee MDPI, Basel, Switzerland. This article is an open access article distributed under the terms and conditions of the Creative Commons Attribution (CC BY) license (http:/ / creativecommons.org/licenses/by/4.0/). 